\title{
Long term neurodevelopmental outcome of preterm infants with periventricular- intraventricular hemorrhage
}

\author{
Periventriküler-intraventriküler kanaması bulunan prematür bebeklerin uzun dönem \\ nörogelişimsel sonuçları
}

\author{
Erhan Bayram ${ }^{1}$, Meral Torun Bayram², Yasemin Topcu ${ }^{1}$, Semra Hız ${ }^{1}$, Ertan Kayserili ${ }^{3}$
}

\begin{abstract}
Objectives: To determine the neurodevelopmental morbidity of preterm infants with periventricular- intraventricular hemorrhage, at the age of 4 .
\end{abstract}

Materials and methods: The patients at the age of 4 were evaluated through neurologic examination and motor assessment by a pediatric neurologist and Denver II Developmental Screening Test by a psychologist. The results were compared with Denver II Developmental Screening Test results which had been made at 3-6 and 6-12 months.

Results: Patients with grade III-IV Periventricular-Intraventricular Hemorrhage had significantly lower Denver II Developmental Screening Test results at the age of 4, compared with grade I-II Periventricular-Intraventricular Hemorrhage group. Similarly, $\leq 32$ weeks patients had significantly lower Denver II Developmental Screening Test at the age of 4 when compared with $>32$ weeks patients.

Conclusions: Children who were born $\leq 32$ gestational weeks and/or patients with grade III-IV periventricularintraventricular Hemorrhage have an increased risk of neurologic impairment. All premature infants should be evaluated by Denver II Developmental Screening Test in early childhood period of life. J Clin Exp Invest 2012; 3(3): 326-330

Key words: Prematurity, periventricular hemorrhage, intraventricular hemorrhage

\section{INTRODUCTION}

Prematurity is associated with neurologic, behavioral and cognitive problems. ${ }^{1}$ As a result of the improvements in obstetrics for assisted reproductive techniques, which is usually associated with multiple gestations, the incidence of preterm delivery

\section{ÖZET}

Amaç: Periventriküler-intraventriküler kanaması bulunan prematüre bebeklerin, 4 yaş, nörogelişimsel morbiditelerinin belirlenmesi.

Gereç ve yöntem: Dört yaşındaki hastalar, nörolojik muayene ve motor değerlendirmeleri için bir çocuk nöroloğu tarafından ve Denver II Gelişimsel Tarama Testleri için bir psikolog tarafından değerlendirildi. Sonuçlar, 3-6 ay ve 6-12. ayda yapılan Denver II Gelişimsel Tarama Testleri sonuçları ile karşılaştırıldı.

Bulgular: Evre III-IV periventriküler-intraventriküler kanaması bulunan olguların 4 yaşındaki Denver II Gelişimsel Tarama Testleri, evre I-II periventriküler-intraventriküler kanaması bulunan grupla karşılaştırıldığında belirgin olarak geri idi. Aynı şekilde, $\leq 32$ hafta doğan olgular $>32$ hafta doğanlarla karşılaştıııldığında, 4 yaşındaki Denver II Gelişimsel Tarama Testleri belirgin olarak geri saptandı.

Sonuç: Sonuç olarak, $\leq 32$ gestasyonel haftada doğan ve/veya evre III-IV periventriküler-intraventriküler kanaması olan olgularda nörolojik etkilenme riski artmaktadır. Bütün prematüre bebkler, erken çocukluk döneminde Denver II Gelişimsel Tarama Testi ile değerlendirilmelidir.

Anahtar kelimeler: Prematürite, periventriküler kanama, İntraventriküler kanama

is increasing. ${ }^{2}$ Periventricular hemorrhage-Intraventricular hemorrhage (PVH-IVH) is a common complication of prematurity. ${ }^{3}$ Severe $\mathrm{PVH}-\mathrm{IVH}$ is strongly associated with death or survival with disability. The risk and incidence of brain injury increases with decreasing gestational age.,3 Intraventricular hemorrhage occurs in $40 \%$ of premature neonates

\footnotetext{
${ }^{1}$ Dokuz Eylül University Medicine Faculty, Department of Pediatric Neurology, Izmir, Turkey

${ }^{2}$ Dokuz Eylül University Medicine Faculty, Department of Pediatric Nephrology, İmir, Turkey ${ }^{3}$ Behcet Uz Children's Disease, Training and Surgery Hospital, Izmir, Turkey
}

Correspondence: Erhan Bayram, 
whom weight less than $1500 \mathrm{~g}$. Ninety percent of the hemorrhages occur within the first 3 postnatal days and the remainder by 10 days. ${ }^{5,6}$ Grade I-II $\mathrm{PVH}-\mathrm{IVH}$ is currently the most common cranial ultrasound abnormality diagnosed in the premature infants. Phenobarbital, vitamin $\mathrm{K}$, vitamin $\mathrm{E}$, indomethacin and other medications have been used to prevent severe $\mathrm{PVH}-\mathrm{IVH}$. They have been ineffective and the reduction of the grade of $\mathrm{PVH}-\mathrm{IVH}$ has not resulted in improved long-term neurodevelopmental outcome. ${ }^{7,8}$

Cerebral palsy, developmental disorder, cognitive impairment, learning disabilities and psychiatric problems can be seen in children who had been prematurely born. ${ }^{2}$ Early identification of neurodevelopmental delay implies an early intervention with beneficial effects on development. In literature, there are numerous reports on neurodevelopmental outcome of premature infants with $\mathrm{PVH}-\mathrm{IVH}$. However, most of them are investigations on the first year of life. Long term neurodevelopmental evaluation of the preterm birth children is essential to recognize risk factors and to improve perinatal and neonatal care. ${ }^{9}$ The number of studies about long term neurodevelopmental outcome of preterm infants with PVH-IVH is not enough.

This study aims to investigate the neurodevelopmental morbidity of children at the age of 4 , who had been prematurely born at less than 37 weeks of gestation with $\mathrm{PVH}-\mathrm{IVH}$.

\section{MATERIALS AND METHODS}

Children who had been born less than 37 gestational age, between September 2005-May 2006 and treated in the Neonatal Intensive Care Unit of Dr. Behcet Uz Children's Hospital were included the study. All patients had PVH-IVH, detected by cranial ultrasonography (USG) and/or magnetic resonance imaging (MRI) in nenonatal period. The age of children was corrected for gestational age. All the patients were called and re-evaluated for the long term neurodevelopmental status. The following data were noted: gestational age, gender, grade of hemorrhage, psychomotor development (age at walking, age at first words and sentences), neurological examination (motor functions, muscle tone and cerebral palsy). Mental and psychomotor developments were assessed at 4 year old corrected age using the Denver II developmental screening test (DDSTII) by a psychologist.

The DDSTII covers four areas of development: personal/social, fine-motor/adaptive, gross motor and language development. Delay in a specific area is suspected when a child fails an item that $90 \%$ of same-aged children pass. A child receives a "caution" when failing an item that $75 \%$ to $90 \%$ of sameaged children pass. Each child can receive an overall rating of normal (no delays and a maximum of one caution), suspect ( 2 or more cautions and/or 1 or more delays) or un-testable (if refused one or more items completely to the left of the age line or more than one item intersected by age line in the $75 \%$ to $90 \%$ area). ${ }^{20}$ We classified the DDSTII results as abnormal (2 or more delays in two or more sectors), questionable (at least 2 delays in one of 4 sectors) and normal.

The patients were evaluated through neurologic examination and motor assessment by a pediatric neurologist and DDSTII by at the age of 4 . The results were compared with DDSTII results which had been made at 3-6 months and 6-12 months.

Prematurity is defined as a birth that occurs before 37 completed weeks of gestation. The classification of grades of $\mathrm{PVH}-\mathrm{IVH}$ ranging from I to IV. Grades of PVH-IVH includes grade I, hemorrhage confined to the subependymal germinal matrix; grade II, hemorrhage into the lateral ventricles without ventricular dilatation; grade III, PVH-IVH with ventricular dilation; and grade IV, PVH-IVH with parenchymal involvement. ${ }^{10}$ The local ethic committee approved the study, and informed parental consent was obtained.

\section{Statistical Analysis}

Data were analyzed via Statistical Package for the Social Sciences (SPSS), Version 15.0. Group differences were analysed using the $\mathrm{X}^{2}$ test for categorical data, and paired-sample Student's t-test for continuous variables. A $p$-value $<0.05$ was considered statistically significant.

\section{RESULTS}

The total study population consisted of 66 prematurely born children of less than 37 gestational age which were treated between September 2005 and May 2006. Mortality rate before the age of 4 was 9/66 (13.6\%). Neurologic outcomes were reported for 57 of the infants. Of them, $24(42.1 \%)$ were girls and $33(57.9 \%)$ were boys. When the cases with $\mathrm{PVH}-\mathrm{IVH}$ were graded with the cranial neuroimaging findings, $62,1 \%$ were documented as grade I hemorrhage, $18 \%$ as grade $\mathrm{II}, 6 \%$ as grade $\mathrm{III}$ and $13.9 \%$ as grade IV.

Twenty-one of the infants (36.8\%) were born < 32 weeks gestational age and 23 preterm infants (\%40.3) had a body weight below $1250 \mathrm{gr}$. 
All of the patients had cranial USG and 55/57 $(96.5 \%)$ of the patients had cranial MRI at neonatal period. $14 / 57(24.6 \%)$ of them had cranial MRI at 4 years of age.
In all groups gross motor developmental delay was the most common finding, and the second one was language delay. The DDSTII results according to the grade of hemorrhage summarized at table- 1 .

Table 1. The most common pathological findings in DDSTII follow-up

\begin{tabular}{|c|c|c|c|}
\hline & DDSTII at & DDSTII at & DDSTII at \\
\hline & 3-6 months of age & $6-12$ months of age & 4 years of age \\
\hline \multirow[t]{2}{*}{ Grade I hemorrhage } & $\begin{array}{c}\text { - Gross motor delay } \\
\text { 13/39 (33.4\%) }\end{array}$ & $\begin{array}{l}\text { - Gross motor delay } \\
\text { 7/39 (17.9\%) }\end{array}$ & $\begin{array}{l}\text { - Gross motor delay } \\
\text { 4/39 (10.3\%) }\end{array}$ \\
\hline & $\begin{array}{c}\text { - Language delay } \\
\text { 12/39 (30.8\%) }\end{array}$ & $\begin{array}{l}\text { - Language delay } \\
\text { 5/39 (12.8\%) }\end{array}$ & $\begin{array}{l}\text { - Language delay } \\
\text { 1/39 (2.6\%) }\end{array}$ \\
\hline \multirow[t]{2}{*}{ Grade II hemorrhage } & $\begin{array}{l}\text { - Language delay } \\
\text { 4/11 (36.4) }\end{array}$ & $\begin{array}{l}\text { - Gross motor delay } \\
\text { 3/11 (27.3\%) }\end{array}$ & $\begin{array}{l}\text { - Gross motor delay } \\
\text { 2/11 (18.2\%) }\end{array}$ \\
\hline & $\begin{array}{l}\text { - Gross motor delay } \\
\text { 3/11 (27.3\%) }\end{array}$ & $\begin{array}{l}\text { - Language delay } \\
\qquad 1 / 11(9.1 \%)\end{array}$ & \\
\hline Grade III hemorrhage & $\begin{array}{l}\text { - Gross motor delay } \\
\text { 1/2(\%50) }\end{array}$ & & \\
\hline \multirow[t]{3}{*}{ Grade IV hemorrhage } & $\begin{array}{l}\text { - Language delay } \\
\text { 3/5 (60\%) }\end{array}$ & $\begin{array}{l}\text { - Language delay } \\
\qquad 1 / 5(20 \%)\end{array}$ & $\begin{array}{l}\text { - Language delay } \\
\qquad 1 / 5(20 \%)\end{array}$ \\
\hline & - Gross motor delay & - Gross motor delay & - Gross motor delay \\
\hline & $2 / 5(40 \%)$ & $1 / 5(20 \%)$ & $1 / 5(20 \%)$ \\
\hline
\end{tabular}

The incidence of cerebral palsy according to the grade of hemorrhage at 4 years of age were, $10.3 \%$ for grade I hemorrhage, $18.2 \%$ for grade II hemorrhage and $20 \%$ for grade 4 hemorrhage.

Patients with grade III-IV PVH-IVH had significantly more abnormal DDSTII results at the age of 4 , compared with grade I-II IVH group $(p<0.05)$. Similarly, $\leq 32$ week-patients had significantly more abnormal DDSTII at the age of 4 compared with $>32$ week-patients $(p<0.05)$ (Table-2). However, there was not a significant difference between the $\leq$ $1250 \mathrm{gr}$ and $>1250$ gram patients $(p>0.05)$.

Table 2. The relationship between gestational age and the DII-DST results at the age of 4

\begin{tabular}{lccl}
\hline DIl-DST & $\leq 32$ weeks & $>32$ weeks & \\
\cline { 1 - 3 } Normal & 14 & 26 & $p<0.05$ \\
Abnormal & 12 & 5 & \\
\hline
\end{tabular}

When we compared the low Apgar score (1-min and/or 5-min) patients' DDSTII results at the age of 4 with normal Apgar score patient, there was not a significant difference $(p>0.05)$. Table- 3 shows the results regarding the comparison between the gestational age and the grade of hemorrhage; however, there was not a significant difference between them. We found the same results when we compared $\leq$ 1250 gram and > 1250 gram group with severe hemorrhage $(p>0.05)$.

Table 3. The relationship between gestational age and grade of hemorrhage

\begin{tabular}{lrrrc}
\hline & $\begin{array}{c}\text { Grade I } \\
\text { IVH }\end{array}$ & $\begin{array}{c}\text { Grade II } \\
\text { IVH }\end{array}$ & $\begin{array}{l}\text { Grade III } \\
\text { IVH }\end{array}$ & $\begin{array}{l}\text { Grade IV } \\
\text { IVH }\end{array}$ \\
\hline$\leq 32$ weeks & 22 & 5 & 1 & 3 \\
$>32$ weeks & 17 & 6 & 1 & 2 \\
\hline
\end{tabular}

MRI findings were significantly different in patient with grade III-IV PVH-IVH compared to those with grade I-II PVH-IVH at neonatal period $(p<0.05)$, however, the difference was not significant at the age of $4(p>0.05)$. Magnetic resonance imaging results according to the grade of hemorrhage at neonatal period and 4 years of age are summarized at table-4. 
Table 4. Magnetic resonance imaging results according to the grade of hemorrhage

\begin{tabular}{|c|c|c|c|c|}
\hline & Grade I hemorrhage n(\%) & Grade II hemorrhage & Grade III hemorrhage & Grade IV hemorrhage \\
\hline At neonatal period & $\begin{array}{l}\text {-normal } \\
26(68.4 \%) \\
\text { - PVL } \\
2(5.3 \%) \\
\text {-delayed myelinization } \\
4(10.5 \%) \\
\text { - cerebral atrophy } \\
2(5.3 \%) \\
\text { - cerebral hemorrhage } \\
2(5.3 \%) \\
\text { - delayed myelinization } \\
+ \text { Cc hypoplasia } \\
1(2.6 \%) \\
\text { - HIE } \\
1(2.6 \%)\end{array}$ & $\begin{array}{l}\text {-normal } \\
5(45.5 \%) \\
\text {-hydrocephalus } \\
3(27.3) \\
\text {-delayed myelinization } \\
2(18.2 \%) \\
\text {-cerebral hemorrhage } \\
1(9.1 \%)\end{array}$ & $\begin{array}{l}\text {-normal } \\
\quad 1(50 \%) \\
\text {-cerebral hemorrhage } \\
\quad 1(50 \%)\end{array}$ & $\begin{array}{l}\text {-hydrocephalus } \\
2(50 \%) \\
\text {-cerebral hemorrhage } \\
1(25 \%) \\
\text {-encephalomalacia } \\
1(25 \%)\end{array}$ \\
\hline Total & 38 & 11 & 2 & 4 \\
\hline At 4 years of age & $\begin{array}{l}\text { - normal } \\
4(50 \%) \\
\text {-gliotic lesion } \\
2(25 \%) \\
\text {-cerebral atrophy } \\
2(25 \%)\end{array}$ & $\begin{array}{l}\text {-normal } \\
\quad 2(50 \%) \\
- \text { PVL } \\
\quad 2(50 \%)\end{array}$ & & $\begin{array}{l}\text { - normal } \\
1(50 \%) \\
\text {-gliotic lesion } \\
1(50 \%)\end{array}$ \\
\hline Total & 8 & 4 & 0 & 2 \\
\hline
\end{tabular}

PVL: Periventricular leukomalacia, cc: corpus callosum, HIE: Hypoxic ischemic encephalopathy

\section{DISCUSSION}

Advances in specialized obstetric and neonatal intensive care in the past several decades have led to a dramatic decline in mortality rates for preterm infants, particularly for extremely low birth weight infants. ${ }^{11}$ However, despite the significant advances in obstetric and neonatal care, PVH-IVH cannot be prevented.

Severe PVH-IVH was observed in approximately $11 \%$ of the neonates weighing less than 1000 $\mathrm{g}$ and in $5 \%$ of those between 1000- and 1250-g body weight. Late preterm infants (33-36 gestation weeks) are reported to be at higher risk for mortality and morbidity than term infants. In the last two decades, this population has increased progressively, and it actually represents the $70 \%$ of the whole preterm population. ${ }^{12}$ In our study, twenty-one infants $(36.8 \%)$ born < 32 weeks gestational age and 23 premature infants $(\% 40.3)$ had a body weight below $1250 \mathrm{gr}$.

Denver II Developmental Screening Test was used to detect developmental outcome. One of the oldest and best known developmental screening test is the Denver-II and the sensitivity of DDSTII was found as $83 \%{ }^{13}$ There was a significant dif- ference, when we compared the DDSTII results at the age of 4 with 3-6 months and 6-12 months. In a study which compared the same patient's 6-12 month and 3-6 month DDSTII results, there was a significant difference between them. ${ }^{14}$ Gross motor developmental delay was the most common finding, and the second one was language delay. In all groups, the rate of the abnormal DDSTII results decreased with age. It is possible that environmental and socioeconomic factors may have had some effect on these findings.

The developmental outcome in preterm infants was associated with gestational age, birth weight, severity of respiratory distress and five-minute Apgar score..$^{15}$ In literature, it has been reported that, severe PVH-IVH (Grade III-IV) is associated with severe neurologic sequelae..$^{16}$ In our study we detected that, patients with grade III-IV PVH-IVH had significantly lower DDSTII results at the age of 4 compared with grade I-II PVH-IVH group and also $\leq 32$ weeks patients had significantly lower DDSTII results at the age of 4 compared with > 32-week patients. The incidence of cerebral palsy was increased with the grade of hemorrhage. Patra et al reported the incidence of cerebral palsy $24.8 \%$ in infants with $\mathrm{PVH}-\mathrm{IVH}$ without ventricular dilatation. ${ }^{17}$ 
In a study, only five-minute Apgar score significantly predicted the gross motor and fine motor outcomes while the psychosocial outcome was associated with five-minute Apgar score and birthweight. ${ }^{15}$ However, when we compared the low Apgar score (1-min and/or 5-min) patient's DDSTII at the age of 4 with normal Apgar score patient, there was not a significant difference. The prognostic value of Apgar score in determining long term neurodevelopmental abnormalities is controversial. We conclude that there is not a significant association between low Apgar scores and long term neurodevelopmental outcome.

Magnetic resonance imaging may indicate the normal development of the preterm brain and can identify diffuse damage. ${ }^{18} \mathrm{MRI}$ findings were significantly different in patient with grade III-IV PVH-IVH when compared to those with grade I-II PVH-IVH at neonatal period; however, the difference was not significantly higher at the age of 4 .

In conclusion, children who were born $\leq 32$ gestational weeks and/or patients with grade III-IV $\mathrm{PVH}-\mathrm{IVH}$ have an increased risk of neurologic impairment and all premature infants should be evaluated by DDSTII in early childhood period of life.

\section{REFERENCES}

1. Wood NS, Marlow N, Costeloe K, Gibson AT, Wilkinson AR. Neurologic and developmental disability after extremely preterm birth: EPICure Study Group. N Engl J Med 2000;343(6):378-84.

2. Arpino C, Compagnone E, Montanaro ML, et al. Preterm birth and neurodevelopmental outcome: a review. Childs Nerv Syst 2010;26(9):1139-49.

3. Hamrick SEG, Miller SP, Leonard C, et al. Trends in severe brain injury and neurodevelopmental outcome in premature newborn infants: the role of cystic periventricular leukomalacia. J Pediatr 2004;145(5):593-9.

4. Simpson J M, Evans N, Gibberd R W, Heuchan AM, Henderson-Smart DJ. Analysing differences in clinical outcomes between hospitals. Qual Saf Health Car. 2003;12(4):257-62.

5. Volpe JJ. Neurology of the Newborn. 4th ed. Philadelphia, PA: Saunders WB; 2001.

6. Perlman JM, Volpe JJ. Intraventricular hemorrhage in extremely small premature infants. AJDC 1986;140(11):122-4.
7. Volpe JJ. Intracranial hemorrhage: germinal matrix-intraventricular hemorrhage of the premature infant. In: Neurology of the Newborn. 4th ed. Philadelphia: WB Saunders; 1995:462- 9.

8. Schmidt B, Davis P, Moddemann D, et al. Long-term effects of indomethacin prophylaxis in extremely-lowbirth-weight infants. N Engl J Med 2001;344(26):1966 -72 .

9. Brévaut-Malaty $V$, Busuttil M, Einaudi MA, Monnier AS, D'Ercole C, Gire C. Longitudinal follow-up of a cohort of 350 singleton infants born at less than 32 weeks of amenorrhea: neurocognitive screening, academic outcome, and perinatal factors. Eur J Obstet Gynecol Reprod Biol 2010;150(1):13-8.

10. Papile LA, Burstein J, Burstein R, Koffler H. Incidence and evolution of subependymal and intraventricular hemorrhage: a study of infants with birthweights less than $1500 \mathrm{~g}$. J Pediatr 1978;92(4):529-34.

11. Lemons JA, Bauer CR, Oh W, et al. Very-low-birthweight outcomes of the National Institute of Child Health and Human Development Neonatal Research Network, January 1995 through December 1996. Pediatrics 2001;107(1):1-8.

12. Engle WA, Tomashek KM, Wallman C, the Committee on Fetus and Newborn. Late-preterm infants: a population at risk. Pediatrics 2007;120(6):1390-401.

13. Glascoe FP, Byrne KE, Ashford LG, Johnson KL, Chang B, Strickland B. Accuracy of the Denver-II in developmental screening. Pediatrics 1992;89(6 Pt 2):1221-5.

14. Bayram M, Kayserili E, Agin H, Bayram E, Unalp A. Evaluation of Short-Term Neurodevelopmental Outcomes in the Premature Patients with Periventricular-Intraventricular Hemorrhage. J. Ped Neurology 2008;6(4):1-2.

15. Piekkala P, Kero P, Sillanpaa M, Erkkola R. The developmental profile and outcome of 325 unselected preterm infants up to two years of age. Neuropediatrics 1988;19(1):33-40.

16. Volpe JJ. Intracranial hemorrhage: Germinal matrixintraventricular hemorrhage of the premature infant. In: Neurology of the Newborn $4^{\text {th }}$ ed. Philadelphia: Saunders WB; 1995:437- 54.

17. Patra K, Wilson-Costello D, Taylor HG, Mercuri-Minich N, Hack M. Grades I-II intraventricular hemorrhage in extremely low birth weight infants: effects on neurodevelopment. J Pediatr 2006;149(2):169-73.

18. Childs AM, Cornette L, Ramenghi LA, et al. Magnetic resonance and cranial ultrasound characteristics of periventricular white matter abnormalities in newborn infants. Clin Radiol 2001;56(8):647-55. 